\title{
SIKAP SISWA TERHADAP PEMBELAJARAN GEOMETRI MELALUI MODEL PACE BERBANTUAN GEOGEBRA
}

\author{
Nurfadilah Siregar $^{1}$, Nani Ratnaningsih ${ }^{2}$ \\ ${ }^{1}$ Universitas Siliwangi \\ nurfadilahsiregar@unsil.ac.id \\ ${ }^{2}$ Universitas Siliwangi \\ naniratnaningsih@unsil.ac.id
}

\begin{abstract}
ABSTRAK
Tujuan dari penelitian ini adalah untuk melihat sikap siswa terhadap pembelajaran geoemtri melalui model PACE berbantuan GeoGebra pada salah satu sekolah menengah pertama di Kota Cimahi. Metode yang digunakan dalam penelitian ini adalah deskriptif kuantitatif dengan desain one-shoot case study. Setelah siswa diberi perlakuan selama pembalajaran geometri, yakni dengan menggunakan model PACE berbantuan GeoGebra, diakhir pembelajaran siswa diberi angket skala sikap model Likert yang berisi 21 pernyataan dengan empat pilihan. Hasil penelitian menunjukkan sikap siswa terhadap kelima indikator yang diukur kesemuanya menunjukkan sikap yang positif. Sikap positif yang diperlihatkan siswa antara lain sikap terhadap ketertarikan, keseriusan dan kesenangan selama pembelajaran geometri melalui model PACE berbantuan GeoGebra.
\end{abstract}

Kata Kunci: sikap, model PACE, GeoGebra, media pembelajaran

\begin{abstract}
The aim of this study is to look at students' attitudes towards Geometry learning through the PACE model assisted by GeoGebra in one of junior high school in Cimahi City. The method used in this study is descriptive qualitative with a one-shoot case study design. After students taught during Geometry learning, namely by using the PACE model assisted by GeoGebra, at the end of the learning students are given a Likert model attitude scale questionnaire containing 21 statements with four choices. The results showed that students' attitudes towards the five indicators measured all showed positive attitudes. The attitude shown by the students' answers to the proposed statements shows the positive attitude of students towards interest, seriousness, and pleasure during Geometry learning through the GeoGebra-assisted PACE model.
\end{abstract}

Keywords: attitude, PACE model, GeoGebra, learning media

Format Sitasi: Siregar, N., \& Ratnaningsih, N. (2019). Sikap Siswa Terhadap Pembelajaran Geometri Melalui Model PACE Berbantuan GeoGebra. Kalamatika: Jurnal Pendidikan Matematika, 4(2), 129140. 
Penyerahan Naskah: 8 Mei 2019 || Revisi: 26 Agustus 2019 || Diterima: 25 November 2019

\section{PENDAHULUAN}

Tiga unsur utama dalam pengajaran geometri, yaitu waktu, materi pengajaran, dan metode pengajaran, apabila diterapkan dan ditata secara terpadu akan dapat meningkatkan kemampuan berfikir anak pada tingkatan yang lebih tinggi (Fabiyi, 2017). Namun demikian, apabila guru kurang terbiasa menggunakan metode mengajar yang berbeda dari biasanya, dikhawatirkan siswa menjadi sukar dalam memahami konsep geometri. Sebaliknya bila guru mampu menata dan memadukan ketiga komponen utama pembelajaran geometri, maka siswa dapat melaksanakan tahap berfikir menurut Van Hiele hingga tahap akurasi (Armah \& Kissi, 2019; Y1lmaz \& Koparan, 2015).

Tujuan pengajaran geometri di sekolah menurut Sabandar (Mulyana, 2003) diharapkan dapat memberikan suatu sikap dan kebiasaan sistematik bagi siswa agar bisa memberikan gambaran tentang hubungan-hubungan di antara bangun-bangun geometri serta penggolonganpenggolongan di antara bangun-bangun tersebut. Untuk mencapai hal tersebut diperlukan suatu kondisi yang memberikan kesempatan bagi siswa bisa mengobservasi, mengeksplorasi, mencoba, serta menemukan prinsip-prinsip geometri lewat aktivitas informal untuk kemudian meneruskan dengan kegiatan formal lalu menerapkan apa yang telah mereka pelajari dalam kehidupan sehari-hari (Arbain \& Shukor, 2015).

Secara umum kemampuan geometri yang harus dimiliki siswa menurut (NCTM, 2000) adalah:

1. mampu menganalisis karakter dan sifat dari bentuk geometri, baik 2D atau 3D, dan mampu membangun argumen-argumen matematika mengenai hubungan geometri dengan yang lainnya;

2. mampu menentukan kedudukan suatu titik dengan lebih spesifik dan gambaran hubungan spasial dengan menggunakan koordinat geometri serta menghubungkannya dengan sistem yang lain;

3. aplikasi transformasi dan menggunakannya secara simetris untuk menganalisis situasi matematika;

4. menggunakan visualisasi, penalaran spasial, dan model geometri untuk memecahkan permasalahan. 
Untuk itu NCTM (2000) menganjurkan agar selama pembelajaran geometri siswa dapat memvisualisasikan, menggambarkan, serta memperbandingkan bangun-bangun geometri dalam berbagai posisi, sehingga siswa dapat memahaminya.

Untuk memfasilitasi pembelajaran geometri yang lebih baik dari sebelumnya, penulis mengangkat sebuah model Project, Activity, Cooperative, Exercise (PACE) sebagai pertimbangan untuk memfasilitasi pembelajaran geometri di sekolah agar pengalaman siswa lebih kaya. Menurut (Lee, 1999) pembelajaran model PACE merupakan model pembelajaran konstruktivisme yang berdasarkan pada prinsip: (1) Siswa belajar lebih baik dengan mengkonstruksi pengetahuan mereka sendiri melalui proses terbimbing, (2) Latihan dan umpan balik adalah unsur penting memahami konsep baru, dan (3) Pemecahan masalah secara aktif dalam kelompok mengembangkan pebelajar menjadi aktif.

Adapun masing-masing komponen dari PACE sendiri bukanlah hal yang baru. Model PACE menyediakan sebuah kerangka kerja untuk memadukan proyek dan lembar kerja yang diberikan kepada siswa bersifat kooperatif di dalam sebuah kelas komputer. Model ini menempatkan siswa sebagai pusat belajar, guru sebagai fasilitator yang memimpin dan memandu siswa untuk menemukan serta memahami konsep baru (Dasari, 2009). Selain itu siswa juga memiliki kesempatan yang luas untuk bekerja sebagai sebuah tim yang akan menuliskan serta menyampaikan laporan hasil kerjanya dalam presentasi di depan kelas (Lee, 1999). Menurut Lee (1999) dibandingkan dengan lingkungan belajar kelas konvensional, suatu lingkungan belajar dengan model PACE menyediakan banyak kesempatan kepada siswa dalam mengembangkan kemampuan penalaran statistis mereka, untuk mengeksplorasi, mencari solusi, mengkomunikasikan gagasan, mengadaptasi prosedur penyelesaian, serta memiliki banyak kesempatan untuk mempelajari proses statistis.

Kegiatan pembelajaran melalui model PACE melibatkan komputer baik dalam pembelajaran di laboraturium maupun di kelas biasa. Dalam activity selanjutnya, siswa dikelompokkan pada kelompok kecil dan ditempatkan di sebuah komputer. Penggunaan komputer selanjutnya melibatkan salah satu dynamic geometry software yaitu GeoGebra. Dengan bantuan software ini diharapkan siswa lebih memahami konsep-konsep dalam geometri. Menurut Wees (Rahman, 2011) ada beberapa pertimbangan tentang penggunaan dynamic geometry software seperti GeoGebra dalam pembelajaran matematika, khususnya 
geometri, diantaranya memungkinkan siswa untuk aktif dalam membangun pemahaman geometri.

Program GeoGebra memungkinkan visualisasi sederhana dari konsep geometris yang rumit dan membantu meningkatkan pemahaman siswa tentang konsep tersebut. Putz (Rahman, 2011) menambahkan ketika siswa menggunakan GeoGebra mereka akan selalu berakhir dengan pemahaman yang lebih mendalam pada materi geometri. Hal ini mungkin terjadi karena siswa diberikan representasi visual yang kuat pada objek geometri, siswa terlibat dalam kegiatan mengkonstruksi yang mengarah pada pemahaman geometri lebih mendalam sehingga siswa dapat melakukan penalaran yang baik. Hal lain yang juga dilakukan siswa adalah melaporkan hasil pekerjaannya melalui tulisan dan presentasi di depan kelas. Melalui kegiatan seperti ini siswa mendapatkan pengertian yang lebih bermakna baginya tentang apa yang sedang ia lakukan. Hal ini berarti guru harus selalu siap mendorong siswa untuk mampu berkomunikasi pada setiap pembelajaran. Selain itu Arbain \& Shukor (2015) dalam penelitiannya menyimpulkan bahwa penggunaan GeoGebra dapat membuat siswa terlibat lebih aktif dalam kegiatan pembelajaran dan lebih banyak melibatkan indra lainnya sehingga akan mencapai kesuksesan yang lebih tinggi.

Sikap siswa yang dimaksud dalam penelitian ini adalah sikap siswa terhadap proses pembelajaran melalui model PACE berbantuan GeoGebra. Adapun indikatornya antara lain: siswa menunjukkan ketertarikan, keseriusan dan kesenangan terhadap pembelajaran geometri melalui model PACE berbantuan GeoGebra.

\section{METODE PENELITIAN}

Metode penelitian dalam penelitian ini adalah deskriptif kuantitatif dengan desain oneshoot case study. Sampel yang digunakan dalam penelitian ini diperoleh dengan cara purpossive sampling. Hal ini dilakukan karena ada hal yang harus dipenuhi, yakni penggunaan komputer dalam pembelajaran. SMP IT Fithrah Insani dipilih karena memiliki fasilitas yang memadai untuk dilakukan penelitian, seperti ketersediaan notebook pada setiap siswa. Penggunaan notebook sendiri menjadi salah satu pendukung untuk terlaksananya pembelajaran geometri melalui model PACE berbantuan GeoGebra.

Adapun instrumen yang digunakan dalam penelitian ini adalah skala sikap yang berpedoman pada model Likert yang terdiri dari pernyataan positif dan negatif dengan empat option. Menurut Suherman (Siregar, 2011) pemberian skor untuk setiap pernyataan adalah 1 
(STS), 2 (TS), 3 (S), 4 (SS), untuk pernyataan favorable (pernyataan positif), sebaliknya diberikan skor 1 (SS), 2 (S), 3 (TS), 4 (STS), untuk pernyataan unfavorable (pernyataan negatif). Empat option tersebut berguna untuk menghindari sikap ragu-ragu atau rasa aman dan tidak memihak pada suatu pernyataan yang diajukan pada siswa.

Skala sikap siswa tersebut berkenaan dengan sikap siswa terhadap pembelajaran model PACE dan sikap siswa terhadap pembelajaran berbantuan software GeoGebra. Skala sikap yang dibuat mempunyai indikator: 1) Siswa menunjukkan ketertarikan terhadap pembelajaran dengan membentuk kelompok; 2) Siswa menunjukkan kesenangan terhadap pembelajaran menggunakan Lembar Aktivitas Siswa: 3) Siswa menunjukkan keseriusan dalam mengerjakan latihan; 4) Siswa menunjukkan kesenangan dan kesungguhan dalam mengerjakan proyek yang diberikan guru lalu menempilkannya di depan kelas; dan 5) Siswa menunjukkan kesenangan, manfaat dan kesanggupan menggunakan software GeoGebra selama pembelajaran.

Agar perangkat skala sikap ini memenuhi persyaratan yang baik, maka skala sikap yang telah dibuat terlebih dahulu diuji face validitynya dengan meminta pertimbangan rekan sejawat dan dosen, sehingga diperolehlah 21 butir pernyataan yang digunakan sebagai instrumen penelitian. Instrumen skala sikap dalam penelitian ini diberikan kepada siswa setelah semua kegiatan pembelajaran geometri dengan model PACE berakhir.

Untuk menganalisa respon siswa pada skala sikap yang diberikan, digunakan dua jenis skor respon yang dibandingkan yaitu, skor respon siswa yang diberikan melalui angket dan skor respon netral. Jika skor subjek lebih besar daripada jumlah skor netral, maka subjek tersebut mempunyai sikap positif. Sebaliknya jika skor subjek kurang dari jumlah skor netral maka subjek tersebut memiliki sikap negatif.

\section{HASIL DAN PEMBAHASAN}

Langkah awal untuk menganalisis sikap siswa dilakukan dengan memberikan skor pada setiap butir pernyataan siswa dengan berpedoman pada skala sikap model Likert. Skor baku skala sikap ditentukan berdasarkan proporsi jawaban siswa pada tiap option. Proporsi tersebut dikonversi menjadi skala menggunakan nilai $Z$. Untuk menghindari skor negatif, nilai $Z$ di transformasi ke $(Z+4,4)$ dan dibulatkan menjadi $Z$ '. Selanjutnya analisis sikap siswa dilakukan dengan membandingkan rata-rata skor sikap siswa dengan skor netralnya pada 
setiap pernyataan dan indikator. Sikap siswa dikatakan positif jika skor sikap siswa untuk setiap butir pernyataan lebih besar dari skor netralnya, demikian juga sebaliknya.

Analisis sikap siswa dilakukan dengan membandingkan rata-rata skor sikap siswa dengan skor netralnya pada setiap pernyataan dan indikator. Pada angket tidak menggunakan pilihan netral, sehingga skor netral setiap pernyataan diperoleh dari rata-rata skor option untuk pernyataan tersebut, begitu juga untuk skor netral setiap indikator, diperoleh dari rata-rata skor setiap pernyataan yang terdapat dalam indikator. Misalnya sebuah pernyataan dengan skor opsi jawaban STS, TS, S dan SS berturut-turut 6, 5, 3, 1 maka skor netral item tersebut adalah 3,75. Skor netral indikator adalah rata-rata dari skor netral itemnya. Sikap siswa dikatakan positif jika rata-rata skor sikap siswa untuk setiap butir pernyataan lebih besar dari skor netralnya. Sebaliknya sikap siswa dinyatakan negatif jika rata-rata skor sikap kurang dari skor netral.

Analisis sikap siswa dilakukan dilihat dari perbandingan rata-rata skor netral dan sikap siswa terhadap semua indikator, maka secara keseluruhan sikap siswa adalah positif. Adapun rinciannya adalah sebagai berikut.

\section{Sikap Siswa terhadap Pembelajaran Model PACE}

Sikap siswa pada aspek ini dilihat dari empat buah indikator. Berikut ini penjelasannya.

1. Menunjukkan ketertarikan terhadap pembelajaran dengan membentuk kelompok. Terdapat 6 buah pernyataan yang harus diisi siwa, dengan 4 buah pernyataan positif dan 2 pernyataan negatif. Distribusi rata-rata sikap siswa untuk indikator tersebut dapat dilihat pada tabel 1.

Tabel 1. Distribusi Sikap Siswa pada Indikator 1.1

\begin{tabular}{lcccccc}
\hline \multicolumn{1}{c}{ Indikator } & \multirow{2}{*}{ Item } & \multicolumn{2}{c}{ Skor Netral } & \multicolumn{2}{c}{ Skor Sikap } & \multirow{2}{*}{ Sikap } \\
& & Item & Kelas & Item & Kelas & \\
\hline Menunjukkan ketertarikan terhadap pembelajaran & 1 & 3,75 & & 4,44 & & \\
dengan membentuk kelompok & 2 & 3,25 & 3,88 & 4,28 & \multirow{2}{*}{ Positif } \\
& 3 & 5,00 & & 4,50 & & \\
\hline
\end{tabular}

Secara umum sikap siswa terhadap indikator pertama adalah positif. Hal ini dapat dilihat dari rata-rata skor sikap kelas untuk semua item atau butir pernyataan lebih besar daripada skor netral kelasnya. Hanya pada pernyataan ke tiga, skor netralnya lebih besar daripada skor sikap. 
Adapun pernyataannya nomor tiga adalah "Belajar secara kelompok membuat saya menjadi kurang percaya diri”. Pernyataan ini adalah pernyataan negatif, sedangkan skor sikap siswa setelah dibandingkan dengan skor netralnya juga negatif. Dapat disimpulkan siswa tidak merasa terbebani dengan belajar kelompok, atau dengan kata lain belajar secara kelompok tidak membuat siswa menjadi kurang percaya diri.

2. Menunjukkan kesenangan terhadap pembelajaran menggunakan Lembar Aktivitas Siswa. Terdapat 3 buah pernyataan yang harus diisi siwa, dengan 2 buah pernyataan positif dan 1 pernyataan negatif. Distribusi rata-rata sikap siswa untuk indikator tersebut dapat dilihat pada tabel 2.

Tabel 2. Distribusi Sikap Siswa pada Indikator 1.2

\begin{tabular}{|c|c|c|c|c|c|c|}
\hline \multirow{2}{*}{ Indikator } & \multirow{2}{*}{ Item } & \multicolumn{2}{|c|}{ Skor Netral } & \multicolumn{2}{|c|}{ Skor Sikap } & \multirow{2}{*}{ Sikap } \\
\hline & & Item & Kelas & Item & Kelas & \\
\hline \multirow{3}{*}{$\begin{array}{l}\text { Menunjukkan kesenangan } \\
\text { terhadap pembelajaran } \\
\text { menggunakan Lembar Aktivitas } \\
\text { Siswa }\end{array}$} & 5 & 4,50 & \multirow{3}{*}{4,00} & 4,50 & \multirow{3}{*}{4,59} & \multirow{3}{*}{ Positif } \\
\hline & 6 & 3,75 & & 4,56 & & \\
\hline & 7 & 3,75 & & 4,72 & & \\
\hline
\end{tabular}

Umumnya sikap siswa terhadap indikator kedua adalah positif. Hal ini dapat dilihat dari rata-rata skor sikap kelas untuk semua item atau butir pernyataan lebih besar daripada skor netral kelasnya. Pada pernyataan pertama, skor netralnya sama dengan skor sikap, bila dilihat kecendrungan pernyataan tersebut bersifat negatif, "Saya lebih memahami materi yang diberikan oleh guru secara langsung tanpa harus mengerjakan LAS”, ini bertentangan dengan sikap siswa yang positif. Namun demikian, dari keseluruhan indikator pernyataan dapat disimpulkan sikap siswa terhadap pembelajaran menggunakan LAS adalah positif.

3. Menunjukkan keseriusan dalam mengerjakan latihan pada saat pembelajaran. Terdapat 3 buah pernyataan yang harus diisi siwa, dengan 2 buah pernyataan negatif dan 1 pernyataan positif. Distribusi rata-rata sikap siswa untuk indikator tersebut dapat dilihat pada tabel 1.

Tabel 3. Distribusi Sikap Siswa pada Indikator 1.3

\begin{tabular}{lcccccc}
\hline \multicolumn{1}{c}{ Indikator } & \multirow{2}{*}{ Item } & \multicolumn{2}{c}{ Skor Netral } & \multicolumn{2}{c}{ Skor Sikap } & \multirow{2}{*}{ Sikap } \\
\hline Menunjukkan keseriusan dalam & 8 & Item & Kelas & Item & Kelas & \\
mengerjakan latihan pada saat & 9 & 4,75 & & 4,50 & & \\
pembelajaran & 10 & 4,00 & 4,17 & 4,67 & 4,44 & \multirow{2}{*}{ Positif } \\
& & 3,75 & & 4,17 & & \\
\hline
\end{tabular}

Sikap siswa terhadap indikator ketiga adalah positif. Hal ini dapat dilihat dari ratarata skor sikap kelas untuk dua buah item atau butir pernyataan lebih besar daripada skor netral kelasnya. Hanya pada pernyataan pertama, skor netralnya lebih besar daripada skor sikap. Artinya sikap siswa untuk pernyataan tersebut adalah negatif, berikut adalah 
pernyataannya: "Saya dapat mengerjakan semua latihan yang diberikan oleh guru di akhir pembelajaran". Pernyataan tersebut adalah pernyataan positif, terlihat bahwa siswa sepertinya tidak mampu mengerjakan latihan yang diberikan oleh guru, walaupun demikian secara umum sikap siswa terhadap indikator ketiga adalah positif. Artinya, siswa menunjukkan kesanggupan dalam mengerjakan latihan yang diberikan.

4. Menunjukkan kesenangan dan kesungguhan dalam mengerjakan proyek yang diberikan guru lalu menampilkannya di depan kelas. Terdapat 3 buah pernyataan yang harus diisi siwa, dengan 2 buah pernyataan negatif dan 1 pernyataan positif. Distribusi rata-rata sikap siswa untuk indikator tersebut dapat dilihat pada tabel 4.

Tabel 4. Distribusi Sikap Siswa pada Indikator 1.4

\begin{tabular}{|c|c|c|c|c|c|c|}
\hline \multirow{2}{*}{ Indikator } & \multirow{2}{*}{ Item } & \multicolumn{2}{|c|}{ Skor Netral } & \multicolumn{2}{|c|}{ Skor Sikap } & \multirow{2}{*}{ Sikap } \\
\hline & & Item & Kelas & Item & Kelas & \\
\hline \multirow{5}{*}{$\begin{array}{l}\text { Menunjukkan kesenangan dan } \\
\text { kesungguhan dalam mengerjakan } \\
\text { proyek yang diberikan guru lalu } \\
\text { menampilkannya di depan kelas }\end{array}$} & 11 & 3,5 & \multirow{5}{*}{3,80} & 4,11 & \multirow{5}{*}{4,41} & \multirow{5}{*}{ Positif } \\
\hline & 12 & 4,25 & & 4,67 & & \\
\hline & 13 & 4,00 & & 4,56 & & \\
\hline & 14 & 3,5 & & 4,06 & & \\
\hline & 15 & 3,75 & & 4,67 & & \\
\hline
\end{tabular}

Pada indikator terakhir dari aspek pembelajaran melalui model PACE terlihat sikap siswa positif. Hal ini dapat dilihat dari rata-rata skor sikap item untuk semua pernyataan lebih besar daripada skor netral itemnya. Artinya sikap siswa untuk pernyataan tersebut adalah positif, terlihat bahwa siswa sepertinya senang mengerjakan proyek yang diberikan oleh guru lalu menampilkannya di depan kelas.

\section{Sikap Siswa terhadap Pembelajaran Berbantuan Software GeoGebra}

Sikap siswa pada aspek ini hanya dilihat dari sebuah indikator. Adapun indikatornya adalah "Siswa menunjukkan kesenangan dan kesanggupan menggunakan software GeoGebra". Distribusi rata-rata sikap siswa untuk indikator tersebut dapat dilihat pada tabel 5.

Tabel 5. Distribusi Sikap Siswa pada Indikator 2.1

\begin{tabular}{lcccccc}
\multicolumn{1}{c}{ Indikator } & \multirow{2}{*}{ Item } & \multicolumn{2}{c}{ Skor Netral } & \multicolumn{2}{c}{ Skor Sikap } & \multirow{2}{*}{ Sikap } \\
& & Item & Kelas & Item & Kelas & \\
Menunjukkan kesenangan dan & 16 & 4,00 & & 4,44 & & \\
kesanggupan menggunakan & 17 & 3,75 & & 4,50 & & \multirow{2}{*}{ Positif } \\
software GeoGebra & 18 & 3,25 & 3,88 & 4,11 & & \\
& 19 & 4,50 & & 4,50 & & \\
& 20 & 4,25 & & 4,33 & \\
& 3,50 & & 4,28 & \\
\hline
\end{tabular}


Dari Tabel 5 terlihat skor sikap siswa untuk semua item atau butir pernyataan lebih besar daripada skor netralnya. Dapat disimpulkan, pada indikator terakhir siswa menunjukkan sikap positif terhadap pembelajaran menggunakan software GeoGebra.

Pembelajaran membentuk kelompok yang terdapat pada aspek pertama sekaligus indikator pertama menunjukkan hasil bahwa kegiatan tersebut menumbuhkan sikap positif dalam diri siswa. Hal ini dapat dilihat dari besarnya skor sikap siswa terhadap skor netral, walaupun untuk beberapa orang siswa pembelajaran membentuk kelompok membuatnya tidak nyaman. Pada indikator berikutnya, penggunaan Lembar Aktivitas Siswa yang selama ini tidak pernah diberikan oleh guru membuat siswa merasakan hal yang positif. Dengan adanya LAS siswa lebih terbantu untuk memahami materi yang disampaikan oleh guru karena siswa dapat mengulang pembelajaran yang telah diberikan kapan saja dengan petunjuk LAS tersebut.

Setelah siswa memperoleh konsep baru, terdapat lembar evaluasi untuk melihat sejauh mana siswa memahami materi yang diberikan. Hal ini dapat dilihat dari pemberian latihan pada saat pembelajaran. Latihan yang diberikan bersifat individual. Dari hasil angket siswa pada Indikator 1.3 diperoleh gambaran bahwa siswa memiliki sikap positif terhadap latihan yang diberikan. Dari angket tersebut, beberapa siswa menyatakan kekhawatirannya dalam mengerjakan latihan. Mungkin saja hal ini terjadi karena siswa memiliki rasa percaya diri yang rendah. Padahal secara umum siswa merasakan manfaat yang besar setelah diberikan latihan oleh guru, karena siswa dapat mengulang kembali apa yang telah dipelajari dan melihat sejauh mana pengetahuan mereka akan konsep tersebut.

Pada indikator terakhir untuk aspek yang pertama, yaitu mengenai pemberian tugas proyek kepada siswa, secara umum sikap siswa adalah positif. Adanya pemberian tugas yang tidak biasa seperti ini, membuat siswa tertantang untuk mengerjakan tugas tersebut dengan sungguh-sungguh. Hal ini dapat dilihat pada saat siswa menampilkan hasil kerja kelompoknya di depan kelas. Siswa terlihat antusias menjelaskan dan menjawab pertanyaan yang muncul dari kelompok lainnya mengenai hasil kerja kelompok mereka.

Selanjutnya untuk aspek terakhir, yaitu penggunaan software GeoGebra, secara umum siswa menunjukkan kesenangan dan kesanggupan menggunakan software GeoGebra. Hal ini dapat dilihat dari perolehan hasil skor sikap siswa yang lebih besar dari skor netral. Penggunaan komputer sebenarnya bukan hal yang baru bagi siswa di sekolah tempat 
penelitian, tetapi penggunaan software GeoGebra dalam pembelajaran geometri inilah yang menjadi suatu hal yang baru bagi siswa, sehingga membuat siswa tertarik untuk menggunakannya. Sejalan dengan hasil penelitian Arbain \& Shukor (2015) bahwa penggunaan software GeoGebra sangat berguna dalam pembelajran.

\section{KESIMPULAN}

Sikap yang diperlihatkan dari jawaban siswa terhadap pernyataan-pernyataan yang diajukan menunjukkan sikap siswa yang positif terhadap ketertarikan, keseriusan dan kesenangan selama pembelajaran geometri melalui model PACE berbantuan GeoGebra. Hal ini dimungkinkan karena selama proses pembelajaran siswa terlibat aktif dalam membangun konsep ataupun pengetahuan baru karena difasilitasi oleh pembelajaran model PACE berbantuan GeoGebra. Keaktifan siswa terlihat juga pada saat menyajikan produk berupa komik segitiga di akhir pembelajaran. Dengan demikian dapat disimpulkan bahwa sikap siswa yang positif terhadap pembelajaran geometri melalui model PACE berbantuan GeoGebra memiliki efek yang positif bagi siswa.

\section{REFERENSI}

Arbain, N., \& Shukor, N. A. (2015). The Effects of GeoGebra on Students Achievement. Procedia - Social and Behavioral Sciences, 172, 208-214. https://doi.org/10.1016/j.sbspro.2015.01.356

Armah, R. B., \& Kissi, P. S. (2019). Use of the van Hiele Theory in Investigating Teaching Strategies used by College of Education Geometry Tutors. Eurasia Journal of Mathematics, Science and Technology Education, 15(4). https://doi.org/10.29333/ejmste/103562

Dasari, D. (2009). Meningkatkan Kemampuan Penalaran Statistis Mahasiswa Melalui Pembelajaran Model PACE. Disertasi SPS UPI, Tidak Diterbitkan.

Fabiyi, T. R. (2017). Geometry Concepts in Mathematics Perceived Difficult to Learn By Senior Secondary School Students in Ekiti State, Nigeria. IOSR Journal of Research \& Method in Education (IOSRJRME), 07(01), 83-90. https://doi.org/10.9790/73880701018390 
Lee, C. (1999). Computer-Assisted Approach for Teaching Statistical Concepts. Computers in the Schools, 16(1), 193-208. https://doi.org/10.1300/J025v16n01_03

Mulyana, E. (2003). Masalah Ketidaktepatan Istilah Dan Simbul Dalam Geometri SLTP Kelas. 19.

NCTM. (2000). Principles and Standards for School Mathematics (3rd ed.). Retrieved from http://gen.lib.rus.ec/book/index.php?md5=D8E144616E131F23FF015291AE77D10B

Rahman, R. (2011). Pengaruh Pembelajaran Berbantuan Geogebra Terhadap Kemampuan Berpikir Kreatif (Universitas Pendidikan Indonesia). Retrieved from https://risqirahman.wordpress.com/2011/10/11/pengaruh-pembelajaran-berbantuangeogebra-terhadap-kemampuan-berpikir-kreatif/

Siregar, N. (2011). Pembelajaran Geometri melalui Model PACE berbantuan Geogebra sebagai Upaya Meningkatkan Kemampuan Penalaran dan Komunikasi Matematis Siswa SMP. Tesis: TIdak Diterbitkan. Universitas Pendidikan Indonesia.

Yilmaz, G. K., \& Koparan, T. (2015). The Effect of Designed Geometry Teaching Lesson to the Candidate Teachers' Van Hiele Geometric Thinking Level. Journal of Education and Training Studies, 4(1), 129-141. https://doi.org/10.11114/jets.v4i1.1067 
